\title{
Mimari Sunum Paftalarında Görsel Tasarım İlkelerinin Uygulanması Üzerine Öneriler
}

\section{Suggestions on The Implementation of Visual Design Principles in Architectural Presentation Boards}

\author{
Deniz Kürşad \\ Dr. Öğr. Üyesi, Çanakkale Onsekiz Mart Üniversitesi Güzel Sanatlar Fakültesi Grafik Tasarımı Bölümü \\ email: deniz.kursad@hotmail.com (DORCID ID: https://orcid.org/ 0000-0002-9824-5641
}

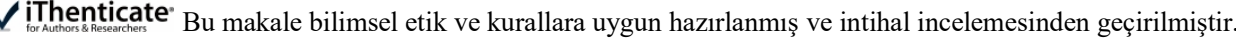

Atıf (APA 6)/To cite this article

Kürşad, D. (2020). Mimari sunum paftalarında görsel tasarım ilkelerinin uygulanması üzerine öneriler. Atatürk Üniversitesi Güzel Sanatlar Enstitüsü Dergisi, 26(44), 211-221. doi: https://doi.org/10.35247/ataunigsed.658247

Makale Gönderim Tarihi/Received: 12/12/2019

Makale Kabul Tarihi/Accepted: 29/02/2020

Makale Yayın Tarihi/Published: 19/03/2020

Research Article / Araștırma Makalesi

\section{$\ddot{O} z$}

Mimarlık ve grafik tasarım disiplinleri, kavram ve uygulama aşamaları anlamında geçmişten bu yana bir geçişkenlik göstermektedir. Bilginin sunumu için belirli ilkelerle hareket eden grafik tasarım, mimari projelerin anlaşılır ve ikna edici bir şekilde sunulmasını sağlayan mimari sunum paftalarında da kullanılmaktadır. Araştırmalar sonucunda, belirli bir standardizasyonu olmayan pafta tasarım uygulamalarının grafik tasarım ilkeleri doğrultusunda incelendiği, metod ve yöntemleri doğrultusunda önerilerin getirildiği kaynakların kısıtlı olduğu görülmüştür.

$\mathrm{Bu}$ çalıșma, Bilgilendirme Tasarımı kapsamında değerlendirilebilecek olan mimari sunum paftaları, bileşenleri ile birlikte bunların grafik sunumu üzerinden değerlendirilecek olup, metot ve yöntemleri doğrultusunda önerileri içermektedir. Çalışmanın aynı zamanda, mimarlık öğrencileri ve sektörde aktif olarak çalışanların daha başarılı paftalar hazırlamalarında bir rehber niteliği taşıması amaçlanmıştır.

Anahtar Kelimeler: Mimari Sunum, Pafta, Layout, Grid, Bilgilendirme Tasarımı, Grafik Tasarım

\begin{abstract}
The disciplines of architecture and graphic design are transitive in terms of concept and application processes. Graphic design, which is based on certain principles for the presentation of information, is used in architectural presentation sheets that allow for the clear and convincing presentation of architectural projects. As a result of previous studies, it was observed that there were a limited number of sources that examined sheet design practices without a specific standardization in accordance with the principles of graphic design and proposed suggestions in line with methods and techniques.

The present study includes the evaluation of architectural presentation sheets, which can be evaluated within the scope of Information Design, along with their components and graphic presentation, and suggestions based on methods and techniques. The study was designed with the aim of providing guidance to architecture students and individuals actively working in the sector and enabling them to prepare more efficient sheets.
\end{abstract}

Keywords: Architectural Presentation, Board, Layout, Grid, Information Design, Graphic Design

\section{Giriș}

Uzun yıllar boyunca, grafik tasarım, endüstriyel tasarım, moda tasarımı ve mimarlık gibi geleneksel disiplinler hep tek başlarına öğretilmiş ve nadiren birbirleriyle ilişkilendirilmiştir (Martin, 2018). Günümüzde ise artık bu durum değişkenlik göstermekte, farklı tasarım disiplinleri uygulamaları bağlamında, kendi aralarında geçişkenlik göstermektedir. Bunlar arasında özellikle grafik tasarım, çoğu disiplinin bilgiyi karşıya etkili bir şekilde, izleyiciyi etkilemek, ikna etmek gibi amaçlarla, belirli tasarım ilkeleri doğrultusunda ve iki ya da 3 boyutlu yüzeylerde aktarmada yararlanılmaktadır.

En önemli amaçlarından biri, bilgiyi en anlaşılır bir biçimde karşıya aktarmak olan grafik tasarımın kullanım alanlarından biri de mimarların projelerini müşterilerine sunmak için kullandıkları mimari sunum paftalarıdır. Literatürde, grafik sunumlar olarak da kullanılmaktadır. Bu çalışmalar, projelerin vaziyet planı, kesitleri, görünüşleri, manuel ya da dijital görselleştirmeleri, piktogram, diagram ve metinler gibi sözlü ve görsel ifadeleri içermektedir. Bu elemanlardan bazıları manuel ya da geleneksel yöntemlerle oluşturuşa bile paftalar günümüzde çoğunlukla bilgisayar destekli programlar ile hazırlanıp sonlandırılmaktadır.

Bilgisayar destekli tasarım araçlarının geçmişi, ilk bilgisayarların geliştirildiği tarih olan 1950'lere kadar uzanır. 1963 yılında Ivan Sutherland tarafından geliştirilen "Sketchpad” bugünkü sistemlerin de temeli olan fikirlerin ilk uygulamalarından sayılabilir. Bu araçların mimarlıkta yaygın olarak kullanılmaya başlanması ise kişisel bilgisayarların ucuzladığı 1980'lerde gerçekleşmiştir. Elle çizim yapma tekniğinden ilham alan katman-tabanlı bilgisayarla çizim sistemleri ilk başlarda biraz dirençle karşılanmakla birlikte, sağladığı hız ve keskinlik gibi faydalardan dolayı mimarlar arasında büyük oranda kabul görmüştür (Pektaş, 2009, s. 81). 
Mimarlar da artık grafik tasarımcıların kullandığı programları kullanmakta, mimari sunum paftalarını oluşturmak için Adobe Photoshop başta olmak üzere Adobe Illustrator, Adobe Indesign progragramlarını öğrenme yoluna gitmektedir. Öyle ki, internet ortamında mimarlara yönelik, sunum paftaları için gerekli olan görsel elemanları düzenleme ve fotoğraf işleme üzerine online derslere rastlanmaktadır (Görsel 1-2).

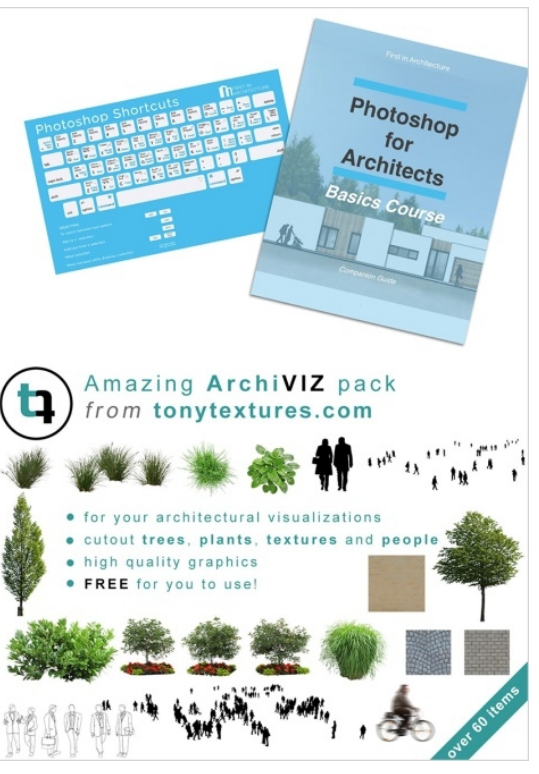

Görsel 1. Mimarlar için online bir kursun tanıtım görseli

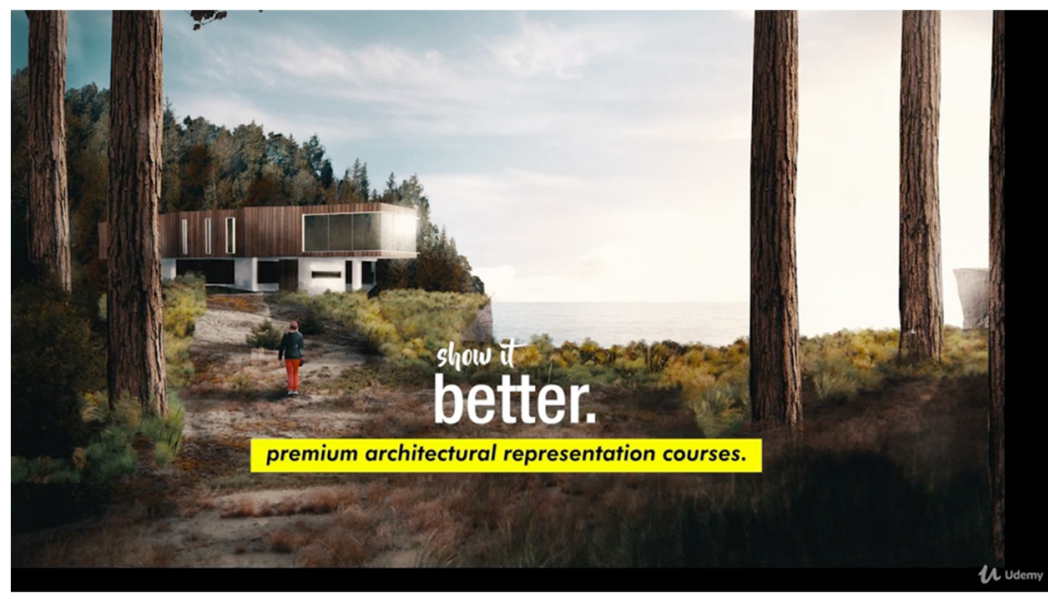

Görsel 2. Udemy’de mimarlara yönelik bir online kursun tanıtım videosu

\section{Yöntem}

Nitel araştırma yönteminin kullanıldığı araştırma kapsamında öncelikle konu ile ilgili literatür taraması yapılarak veriler toplanmıştır. Yorumlanan veriler ile birlikte mimari sunum paftalarının, daha etkili sunumu için bilgilendirme tasarımı kapsamında değerlendirilerek- tasarımları gerçekleştirilirken uygulanması gereken görsel tasarım ilkeleri doğrultusunda öneriler getirilmiştir.

\section{Mimari Sunum Paftaları}

Mimari proje sürecini tamamlamış bir mimarlık öğrencisi ya da profesyonel iş hayatında yer alan bir mimar, projesini jüriye ya da müşterisine (özel, kamu, şahsa ait bir kurum/firma) sunması gerekmektedir. Poster sunumlarında amaçlanan, bilgiyi kısa sürede karşı tarafa etkili ve anlaşılır bir şekilde kısa sürede aktarmaktır. Mimari sunum paftalarında da amaç, izleyiciyi proje hakkında bilgilendirmek, aynı zamanda ikna etmektir. Literatürde "grafik sunum" ya da "grafik pafta" ifadeleri ile de yer alan paftalar, projelerin tasarım sürecini anlatır. Sunumlarda, izleyicinin mekânı tam olarak algılayabilmesi, hissedebilmesi ve onaylaması hedeflenir.

Sunumlar yaklaşık 25 dakika sürdüğünden pafta üzerinde fazla metne gerek duyulmadan çoğunlukla görsel yoğunluklu bir ifade yolu tercih edilmektedir. Konsept paftası olarak da adlandırılan mimari sunum paftaları, 
projeye ait verilerin görselleştirilmesi ile birlikte ilgili harita, teknik çizim, infografik, diyagram gibi detayları da içermektedir ve çoğunlukla AO ya da Al boyutlarında, dikey ya da yatay olarak kullanılabilmektedir.

\section{Mimari Paftaların Bileşenleri}

Mimari sunum paftalarının görsel ve tipografik bileşenlerinin sunumu, mimarın estetik algısına ya da karşı tarafın beklentilerine göre değişebilmektedir. $\mathrm{Bu}$ nedenle, bu bölümde, bir standardizasyon bulunmamakla birlikte paftalarda kullanılabilecek bileșenlerin tümüne yer verilmesi uygun olacaktır.

\subsection{Sunuş Çizimleri}

Mimari üretim iki gerçekliği bir arada içerir: Bunlardan ilkini inşa edilmiş ürünün kendisi, diğerini ise mimarın tasarısını aktaran çizim oluşturur (Köksal, 2009, s. 18). Sunuş çizimleri, mimarın imzası gibidir. Kendine özgü bir teknik ile ifade edilir ve projenin anlaşılır bir biçimde akılda canlandırılmasını sağlaması beklenir. Proje tamamlandığında öngörülen sonucun karşı tarafa en etkili bir biçimde aktarılmasını sağlar. Grafik tasarımın bir alt dalı olan illüstrasyonun kapsamında incelenen mimari illüstrasyonlar, bir bakıma paftalarda yer alan sunuş çizimlerine karşı1lık gelmektedir.

3D görselleştirmeler de sunuş çizimleri içerisinde değerlendirilmekte olup bu görseller daha çok hipergerçekçi bir sonuç aktarmak isteyen tasarımcılar tarafından tercih edilmektedir. 3D mimari görselleştirme çalışmaları için çoğunlukla SkechUp, Lumion 3D, Adobe Photoshop gibi programdan yararlanılmaktadır. İllüstratif tarzda sunulan proje görselleri, aynı zamanda projenin samimi bir duygu aktarımına da yardımcı olmaktadır. Akromatik renk uygulamalarında grafik kalemler ya da mürekkepten yararlanılırken, renkli uygulamalarda ise suluboya, firça kalem ya da pastel boyadan yararlanılabilmektedir. "Sunuş çizimleri, genellikle müşteri veya izleyici için hazırlanırlar bu nedenle ikna edici olabildikleri kadar güçlü sunulmaları ve tasarım projesindeki en makul kısımları ortaya çıkarmaları gerekmektedir. Bu çizimlerin çarpıcı, yapılabilir, kolay anlaşılır ve projenin konseptlerini kolaylıkla iletiyor olmaları lazımdır" (Farrely, 2012, s. 88).

İster dijital ister manuel olarak ifade edilmiş olsun, sunuş çizimlerinde önemli olan, mekânın “yaşıyor” hissinin izleyiciye aktarılmış olmasıdır (Görsel 3). Bu his, doğru bir perspektif ile mekânın, çevre ile ilişkisi, peyzaj, araba, figür, hayvan gibi yardımcı elemanlarla kurulacak bir kompozisyon ile verilebilmektedir.

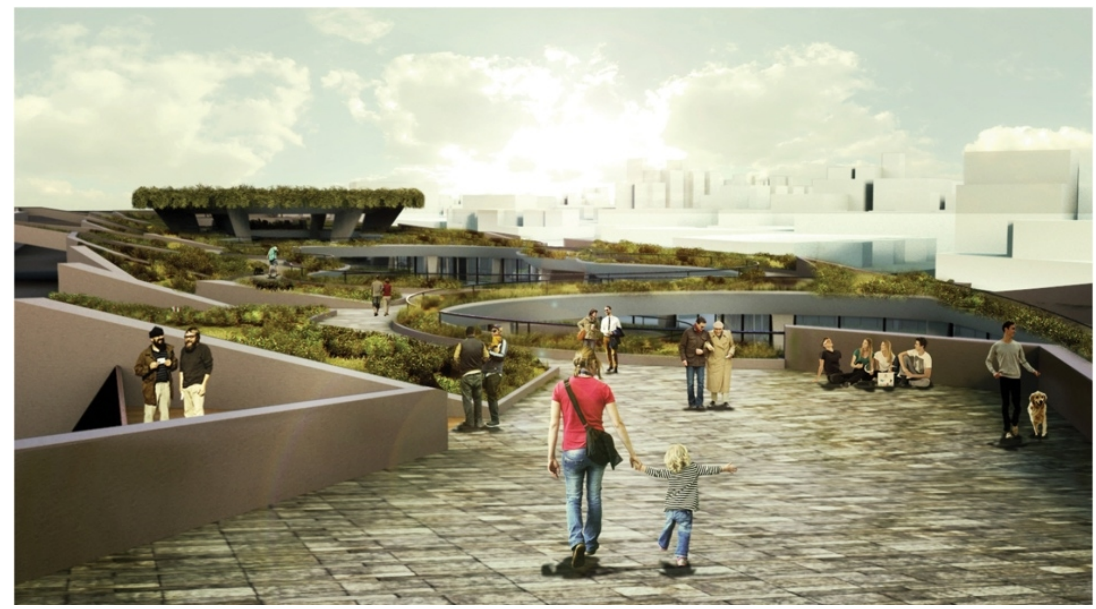

Görsel 3. Hipergerçekçi bir render örneği

\subsection{Destekleyici Metin}

Paftalarda sunuş çizimleri, gerekli bulunduğu taktirde metinle desteklenebilir. Bunlar çoğunlukla çizimlerle ilgili açıklanmak istenen verilerdir. Metnin de bir bakıma sunuş şekli bulunmaktadır ve bu sunuş, yazıyı bir kutu içerisinde ya da zeminle entegre edilmiş bir biçimde olabilir.

\subsection{Lejantlar}

Lejantlar, haritalarda bulunması gereken özellikler arasındadır ve harita işaretleri ya da sembolleri olarak nitelendirilirler. Her haritada, haritanın amacına uygun semboller yer almaktadır. "Gerçekte yeryüzünde noktalar olmadığına göre, harita üzerindeki noktalar bir evi, okulu, camiyi, spor salonunu, sinemayı veya İstanbul gibi bir şehri temsil eden işaretler veya sembollerdir. Bu nedenle haritalar bir lejanda sahip olmalı ve sembollerin ne anlama geldiği açıklanmalıdır” (Demiralp, 2009, s.962). 
Lejantların antet anlamında kullanımı da vardır ki bu, paftaların sağ alt bölümünde yer alır ve projeyi uygulayan kişi ya da kuruluş ile ilgili bilgileri şemaları ifade eder.

\subsection{Piktogramlar}

Mimari literatürde genellikle sembol olarak nitelendirilebilen piktogramlar, bir nesne ya da alanı temsil eden grafik gösterimlerdir. Verilmek istenen mesajı yalın bir üslupta görselleştirerek ortak dile dönüştürebilme becerisine sahiptir (Güler, 2016, s.1521). Sunum paftalarında yer alan kapı, pencere, kesit, yön işaretleri piktogramlara örnektir (Görsel 4).

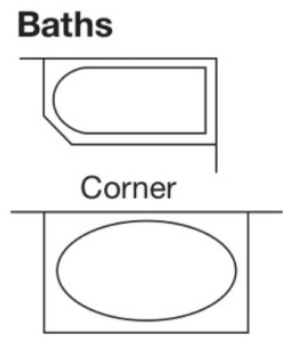

Whirlpoo

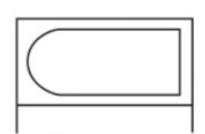

Recessed

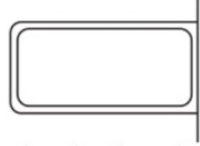

Institutional

or island

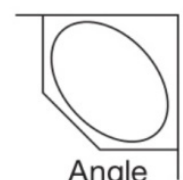

Angle

Görsel 4. Mimari Piktogramlar

\subsection{Tefrișler}

Mimari planlarda kullanılan masa, yatak, vitrin, küvet gibi elemanların şablon görsellerdir.

Tefrişler, çizilen projelerde oluşturulan mekânlara, kullanım sırasında gerekli olan eşyaların uygun şekilde yerleşip yerleşmediğini göstermesi açısından önemlidirler. Özellikle, elektrik ve makine mühendislerinin kendi hesaplamaları için gerekli olan çizimlerini yapabilmeleri, mimari projedeki eşya ve ekipmanların yerleşimine bağlıdır. Genelde tefrişler için sıkça kullanılan eşya, ev ve bahçe mobilyaları ile vitrifiye elemanları vb. çizimler diğer projelerde kullanmak üzere ve farklı kullanıcılar arasında bir dil bütünlüğünün sağlanması için her büroda oluşturulan çizim kütüphanelerinde saklanmaktadır (İnan ve Yıldırım, 2009, s. 593).

\subsection{Diyagramlar}

Bir diyagram, ayrıntılı ölçeklendirme açıklamaları veya gerçekçi resimsel öğeler vermeden soyut olarak temsil eder; belirsiz şekilleri kullanarak mekânsal ilişkileri gösterir (Dulic ve Aladzic, 2016, s. 836). Daha ekonomik yazı kullanımı için diyagramlar doğru bir tercih olabilmektedir (Görsel 5). Diyagramlar aynı zamanda infografik ögelerdir. İnfografik sunumlarda istatistiksel verilerin anlaşılır bir şekilde özetini aktarır. Pasta grafikleri ya da çubuk grafikler buna örnektir.

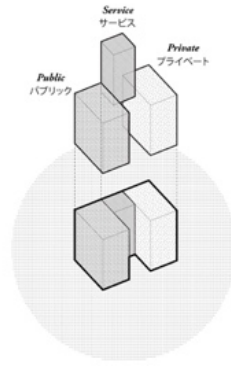

(1)

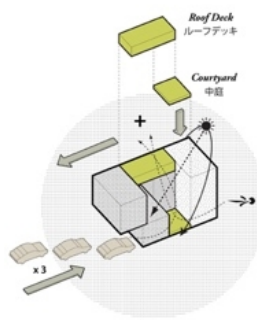

(3)

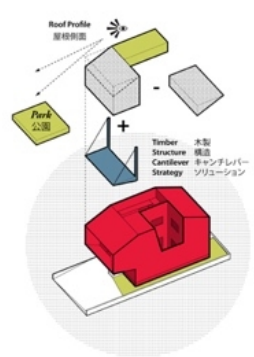

(1)

Görsel 5. Bir diyagram örneği

Diyagram, seçilmiş bir soyutlamanın uzamlaştırılması ve/veya bir kavram veya olgunun indirgenmesi şeklinde tanımlanabilir. Diğer bir deyişle, diyagram bir fikrin veya varlığın mimarisidir. Sözcük, Latince ve Yunancadaki "diagramma" sözcüğünden türetilmiştir. Bu kelime işaretlenen, şekillenen, izlenen, sembol haline getirilen, yazılan veya çizilen şey anlamına gelmektedir (Melikoğlu Eke, 2019, s. 363). 


\section{Başarılı Bir Sunum Paftası için Uygulanması Gereken Prensipler}

Tasarımcılar iki boyutlu bir düzlemde bilgileri doğru bir şekilde organize edebilmek için rehber niteliğindeki görsel tasarım ilkelerini kullanırlar. Bunlar; denge, ritm, vurgu ve odak noktası, hareket, görsel uyum, çeşitlilik, oran, egemenlik, görsel hiyerarşi, plastik ekonomi ve birlikten meydana gelmektedir (Öztuna, 2007, s. 20). Tasarım ögeleri, birçok grafik tasarım yüzeyinde olduğu gibi görsel bir sunumda da kurguyu oluşturan bileşenlerdir ve görsel tasarım ilkeleri de bu bileşenlerin estetik bir şekilde organize edilmesini sağlayan prensiplere karşılık gelir.

\subsection{Layout}

"Kullanılan görsel ögelerin sayısının azaltılması ve bir ızgara sistemine oturtulması kompakt planlama, anlaşılırlık ve açıklık hissi yaratır ve tasarımda düzenliliği öne sürer. Düzenlilik bilgilere inanılırlık katar ve güvenirliği teşvik eder" (Ambrose ve Harris, 2013, s. 94). Paftada kullanılacak olan bilgiler için görünmez bir grid oluşturmak, görsel içeriklerin organize edilmesini kolaylaştırdığı gibi, çalışmaya başlamadan önce tasarımcıya rehberlik eder. İyi kurgulanmış bir layout, paftaya uygun bir hizalama seçeneği belirlendikten sonra pafta bileşenleri arasında oluşturulacak tampon alanlar ile birlikte karmaşadan uzak, etkili ve dengeli bir sunum sağlar. Ayrıca, içeriklerin düzenli, temiz ve okunaklı bir şekilde yerleşmesine olanak tanır. Bazı kaynaklarda tasarım ilkeleri arasında "hizalama" olarak yer alan ifadesi de layout ile ilgilidir. Hizalama, metinler ya da görseller arasında yatay ya da dikey olarak yapılabilir. İçeriklerin, düzenli bir şekilde sunumunu sağladığı için akılda kalma ihtimalini artırır. Hizalama aynı zamanda içeriklerin birbiri ile olan ilişkilerini vurgulamak için de kullanılabilir.

Mimari sunum posterlerinde kullanılan 3 ayrı layout düzeni vardır. Bunlar Izgara Sistemi (Grid), Tek İmaj Sistemi (Single Image) ve Karışık Sistem (Blended) olarak adlandırılmaktadır (Görsel 6). Grid sisteminde, layout bileşenleri bir 1zgara sistemi üzerine oturtulur (Görsel 7).

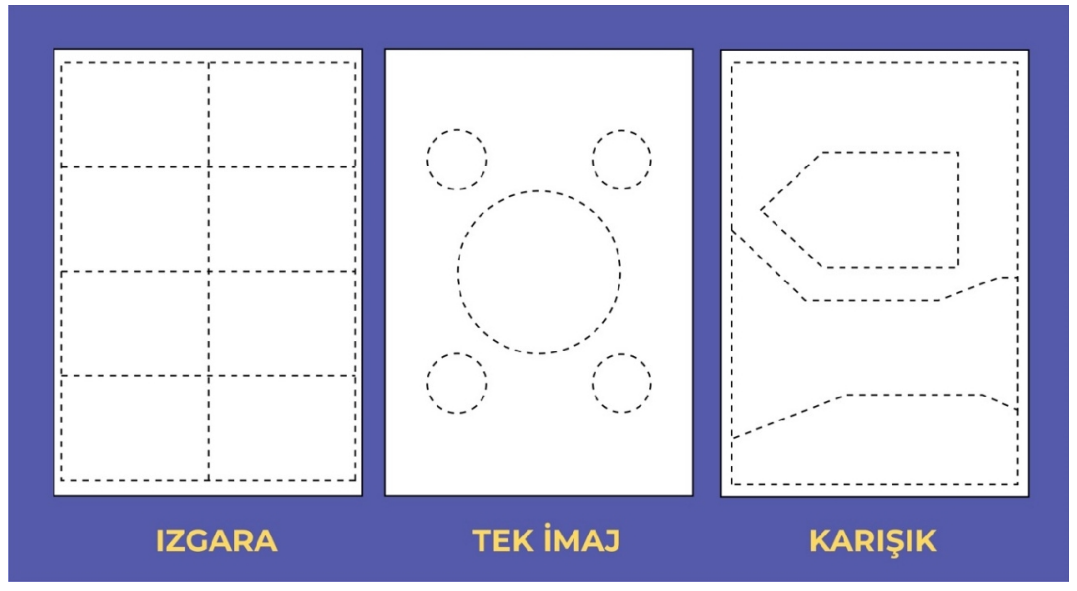

Görsel 6. Farklı Layout düzenleri
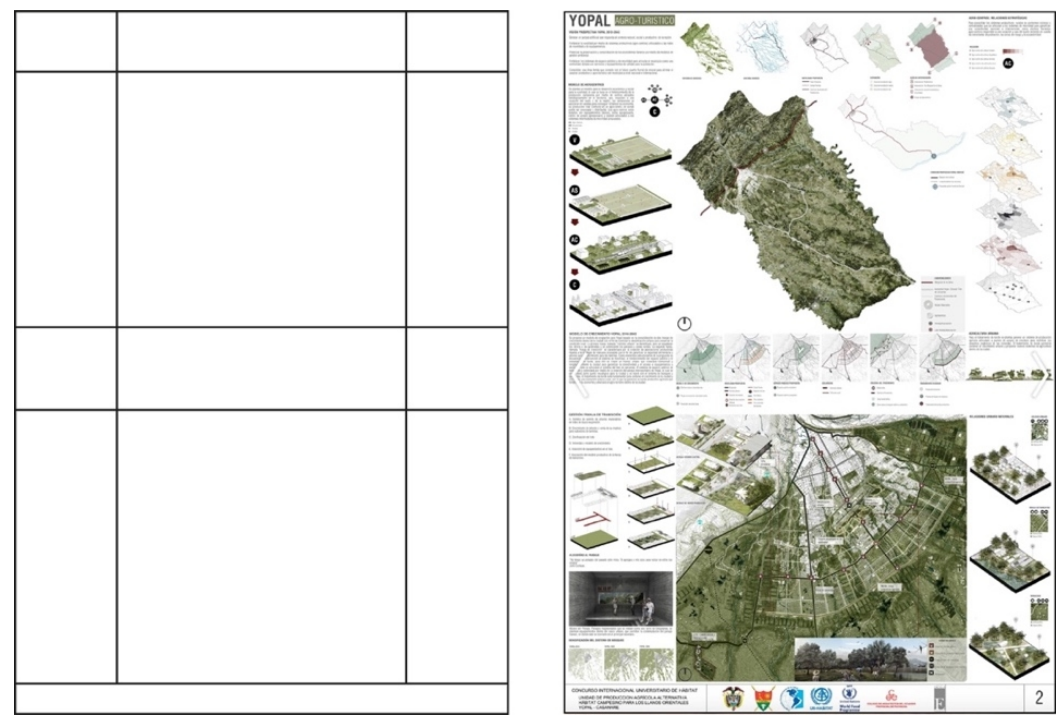

Görsel 7. Grid Pafta Örneği 


\subsection{Arka Plan}

Bir görsel tasarım yüzeyinde arka plan (backround) çoğunlukla dolgu rengi ile oluşturulabildiği gibi çeşitli imgeler ya da patternler ile de desteklenebilmektedir. Yüzeydeki tasarım elemanları ile üst üste gelmediği sürece bu yardımcı zemin elemanlarının kullanılmasında sakınca bulunmamaktadır.

Hem görsel ve metinlerin zeminden ideal bir biçimde ayrışması için, hem de her zaman daha seçkin ve profesyonel sunum imkânı yaratması nedeniyle zemin rengi olarak -bazı durumlar dışında- çoğunlukla beyaz tercih edilmelidir (Görsel 8). Aynı zamanda dikkati dağıtmayarak karışıklığın önüne geçer.

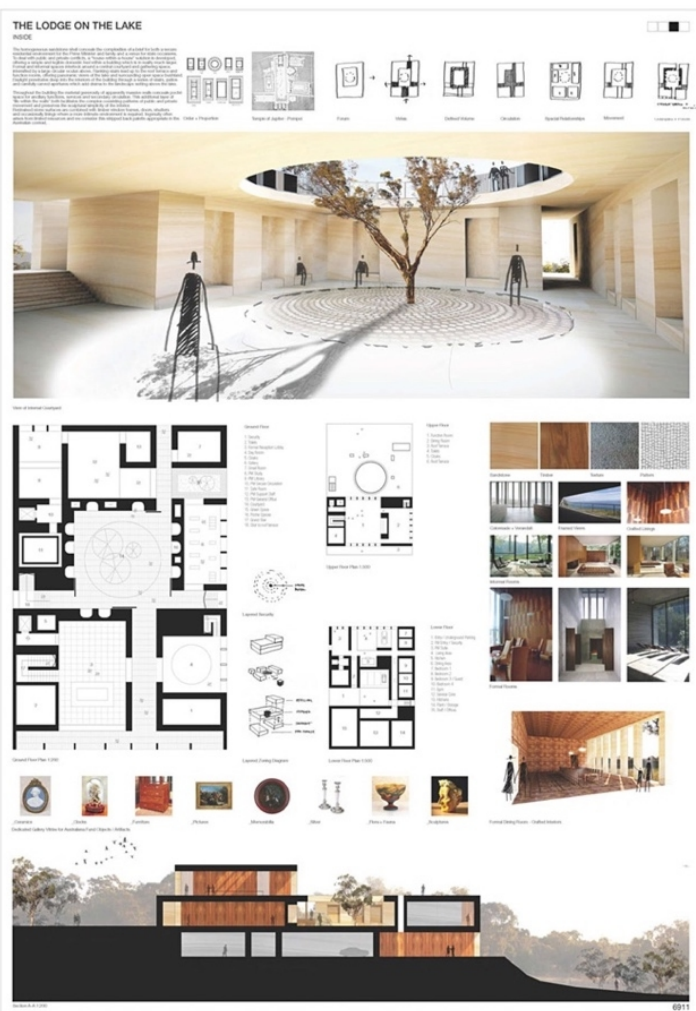

Görsel 8. Beyaz alan kullanımına örnek

Arka plan rengi için, beyaz en iyi seçenek olarak gözükse de bazı özgün düzenlemelerde koyu renkler de tercih edilebiliyor. Bütünlük hissiyatı verebilen güçlü bir görsel dil için; gölgeler, ara tonlar ve degrade arka planlar kullanılabiliyor. Plan ya da kesit gibi belirli çizimleri vurgulamak için ise öğrenciler kontrast renklere sahip bir arka plan oluşturuyor (Burotime, 2019).

Zeminde koyu bir renk tonu ya da siyah tercih edildiği zaman, zemin ile yazılar arasındaki kontrast farkının \%70'ten fazla olmasına dikkat edilmelidir. Böylelikle zaten küçük punto ile sunulacak olacak destekleyici metnin okunurluğu azalmaz (Görsel 9).

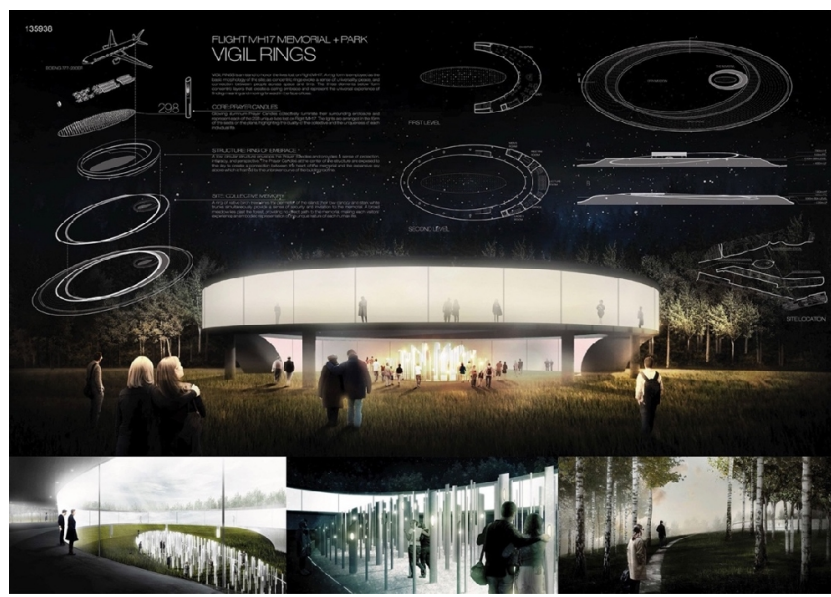

Görsel 9. Koyu zeminde bileşenlerin ideal sunumuna örnek 
Pafta örnekleri incelendiğinde başvurulan yöntemlerden olan yüzeydeki görsel elemanların (Örn. 3D modelleme), düşük opaklı görünümünün zemine uygulanması hem paftanın görsel kalitesini düşüreceği hem de görsel bir karmaşaya yol açtı̆̆ 1 için kaçınılmalıdır.

\subsection{Renk}

Renk, görsel tasarım ögelerinden biridir. Fakat grafik sunumlarda rengin tasarım bileşenlerinin organize edilmesinde de yararlanılan bir eleman olduğu için bu çalışmada, prensipler arasında incelenmiştir. Örneğin renk, görsel ya da tipografik ögelerin gruplanmasına, dolayısıyla izleyiciye görsel hiyerarşiyi kurmasında da yardımcı olur. Bir tasarımda renkler, öne ve arkaya doğru giderler; soğuk ve sıcak görünürler; görsel hareketlilik, illüzyon ve derinlik yaratırlar; biçimleri, şekilleri görünür kılarlar (Öztuna, 2007, s. 141).

Tasarım yüzeylerinde, ilk izlenim çoğunlukla renk vasıtası ile oluşmaktadır. Paftalarda da bu durum geçerlidir. Paftalarda renk, mimari tasarımda kullanılan tarzı yansıtmada yardımcı olacaktır. Örneğin projede ağırlıklı olarak yeşil renk kullanıldıysa paftada konsept olarak yeşil renkten faydalanılabilir. Burada, mimari görselleştirme üzerine gelmesi istenen bir metin ya da başlık için bir fon ya da -varsa- dekoratif görsel ögeler için tercih edilebilir.

Malzeme kullanımına bağlı olarak rengin kullanım yoğunluğu değişebilir. Bu durum çoğunlukla paftada yer alan mimari görselleştirme ögesinde ya da paftayı toparlayıcı ek görsel elemanlarda kendine yer bulabilir. Abartıya kaçmadan konseptin parçası olarak belirlenen rengin kullanımı bir bakıma paftanın kimliğini desteklemede yardımcı olur. İletilmek istenen mesajın ifade edilmesinde yardımcı bir iletişim aracı sayılmaktadır.

\subsection{Görsel Hiyerarşi}

Projeler, belli bir standart oluşturmak için büyüklüğüne ve ölçeğine bağlı olarak A4 olarak isimlendirilen dosya kağıdı ve bunun katları olan DIN normunda kağıtlara çizilmelidir (İnan ve Yıldırım, 2009, s. 592). Paftanın ölçüsü belirlendikten sonra tasarım yüzeyinde kısa sürede izleyiciye öncelikle verilmek istenen mesaj ya da algılaması istenen öncelikli görsel için gözün yönlendirilmeye ihtiyacı vardır. Bu yönlendirmede görsel hiyerarşinin etkisi büyüktür. Böylelikle dikkat çekmesi istenen elemanlar öncelik sırasına göre bir sıraya girer.

Basitçe, üst sol köşeden ya "F" şeklinde (kırmızıyla gösterilen) okumaya ya da sayfa üzerinde sağ üst noktada sonlanacak şekilde göz gezdirmeye (maviyle gösterilen) eğilimliyiz. Bu şekillerin farkında olmak, bilgiyi önem sırasına göre doğru yerleştirmek için değerlidir. Bir sayfayı karelere bölünce, bazı kısımların diğerlerine göre daha fazla hareketlilik içerdiği açıkça görülür (Ambrose ve Harris, 2013, s. 94). (Görsel $10)$

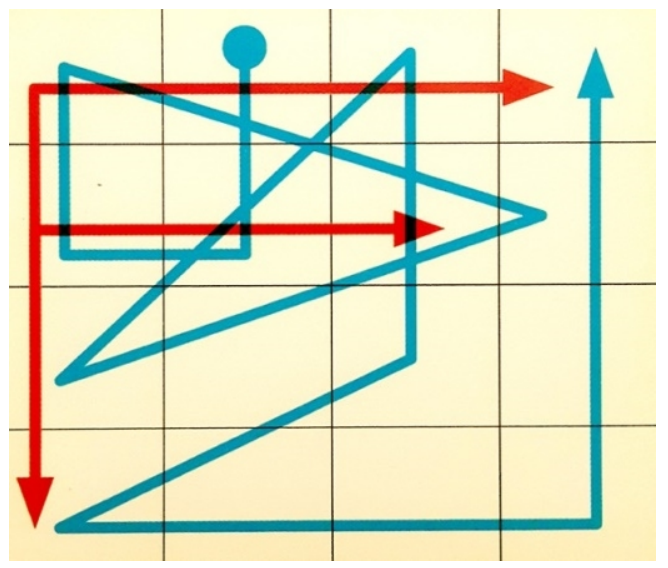

Görsel 10. F Pattern

Mimari paftalarda, gözün izlemesi istenen hareketli bölge öncelikle görsel vurgu, daha sonra metin olmalıdır. Bu elemanlardan sonra gözün, diyagram, aksonometrik çizimler, lejantlar, vaziyet planları gibi ayrıntıları taraması sağlanmalıdır.

Avustralya'da yer alan Simon Pendal isimli mimari tasarım ofisinden mimar ve mimari görselleştirme, mimari sunum üzerine Youtube'da birçok videosu bulunan Chris Mewburn'un 2015 yılında yayınladığı ve Curtin Üniversitesi Mimarlık Okulu adına hazırladığı "Pafta Örnekleri Gösterimine Dayalı Pafta Sunumu Eğitimi" videosunda, "Paftalar giriş, gelişme ve sonuç şeklinde ilerlemesi gerekir. Giriş bölümü daha çok görünümün dişa vurduğu ve konseptimizin anlaşılmasılyla ilgilidir" demektedir (Mewburn, 2015).

Giriș bölümü, projenin ismi ya da tanımlamalar ile ilgili başlık, alt başlık -varsa görsel-, gelişme bölümü konsepti gösteren çizimlerden (plan, kesit vb. bileşenler) ayrıntılardan oluşması gerektiğine dikkat çekmektedir. Son kısım ise bilgilerin birbiri ile ilişkilendirildiği bölüme karşılık gelir. Paftalar bir bakıma bir süreci görsel olarak 
hikayeleştirir. Bu hikâyede bir ana fikir vardır ve bu ana fikrin her zaman ilk bakışta göze çarpması sağlanmalıdır ki bu çoğunlukla geniş bir mimari görselleştirme imajı, yoğun renk ve yüksek kontrastla sağlanmaktadır. İkinci odak noktası için ise daha küçük imajlar, daha az görsel ve destekleyici metinlerden oluşmalıdır. Mewburn (2015) bu konuda, insanların panel (sunum paftası) etrafında 30 saniye döneceklerini ve bu yüzden insanların dikkatini çekmek geretiğine, bunun, konsepti öncelikle metinlerle değil, çizimlerle anlatıldığına emin olunması gerektiğini vurgulamaktadir.

\subsection{Tipografi}

Tipografi kavramı, yazının görsel olarak sunumu olarak nitelendirilebilir. Profesyonel bir tasarımcı, tipografiyi sezgisel olarak kullanıp yönetebilse de, bu alanda yetkin olmayan bir kişinin bilgiyi, görsel ve yazı ile doğru bir şekilde organize etmesi gerektiği durumlarda, tipografiyi ancak konu üzerine araştırmalar yaparak, belirli kurallar çerçevesinde uygulaması, nitelikli bir çalışma ortaya koyabilmesi açısından oldukça önemlidir.

Pafta gibi sunum materyallerinde görsel üzerinde yazının kullanımı, hiyerarşinin kurulması, layoutun bir parçası olarak değerlendirilmesi, zemin rengi ile ilişkisinin çalışmaya katacağı etki açısından ve yüzeyde konumlandırılacağı yazı tipi ve puntosu ile büyük önem taşımaktadır (Görsel 11).

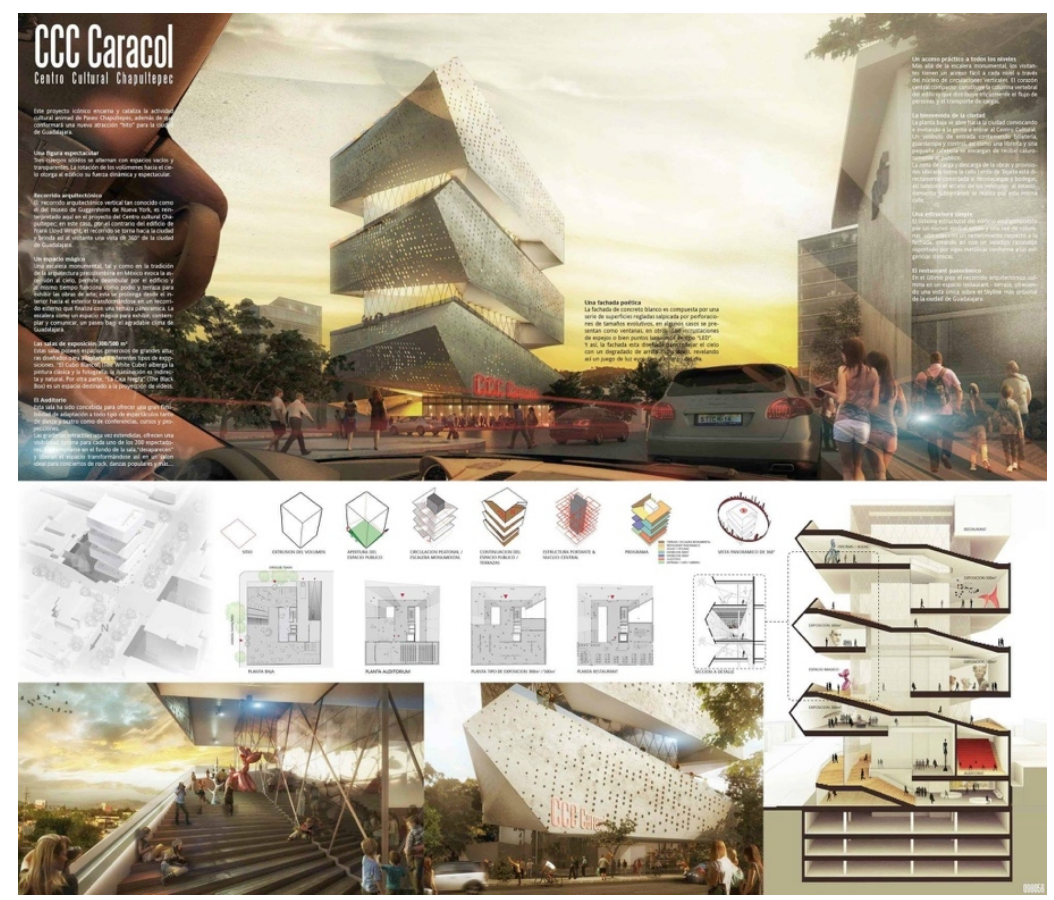

Görsel 11. Tipografinin zeminle kontrast ilişkisine örnek

Birçok grafik yüzeyde olduğu gibi mimari sunum paftalarında proje başlığı ve destekleyici metinde etkili bir tipografi kullanımı öncelikle okunurlukla sağlanmalıdır. Sunum paftalarının A0, A1, A2 gibi farklı boyutlarda uygulandığı düşünüldüğünde başlık ve metin puntoları (harf boyutu) ile ilgili net bir şey söylemek mümkün olmamaktadır. Xulong (2017), 36x72 cm. ölçülerinde bir sunum paftasına yönelik olarak başlık için 36pt, altbaşlık için 24pt ve içerik için 16pt. kullanılmasını önermektedir. Bu boyutlar A2 ölçülerindeki paftalar için de uygundur fakat A0 ölçülerindeki bir paftada puntolardaki bu değerler doğru orantılı olarak uyarlandığ1 taktirde punto ölçüleri, başlık için 72pt., alt başlık için 48 pt. ve içerik metni için 32 pt. olacaktır.

Yazı büyüklüğü kadar yazı tipi de bir o kadar önemlidir. Metinler arası hiyerarşiyi kurmak için de yazı tipini ve birbirleri arasındaki oranın etkisi büyüktür. Bilginin sunumunda tipografide hiyerarşi, başlık, alt başlık ve içerik metninin, aynı yazı tipi ailesinin farklı üyelerinden seçilmesi ile çözümlenmelidir.

Yazı aileleri tasarımcıya birbiriyle temiz ve uyumlu bir şekilde çalışan dolayısıyla kullanışlı tasarım araçları olan bir dizi çeşitleme sunar. Net ve tek biçemli hissi veren bir iş yapabilmek için pek çok tasarımcı kendisini, projenin gerektirdiği beklentileri karşılayabilecek, tipografik hiyerarşi kurmaya elverişli yazı varyasyonlarından sadece iki yazı ailesiyle sinırlandırır (Ambrose ve Harrris, 2011b, s. 68).

Bu prensip bilgiyi temiz bir şekilde sunabilme adına sunum paftalarında da geçerli olmalıdır. Üçüncü bir yazı tipine ihtiyaç duyulduğunda ise aynı font ailesinin italik ya da bold versiyonunun kullanılması daha uygun olacaktır. İstendiği takdirde daha hareketli bir font tercihi yalnızca başlıklarda yapılmalıdır. Destekleyici metinde ise aynı ailenin sans serif (tırnaksız) bir üyesi ya da farklı bir sans serif yazı font tercih edilmesi önerilmektedir. "Çizimlerin çizgi ağırlığının seçimine gelirsek, font büyüklüğü ve stilinin izleyicilerin destekleyici metni 
yorumlamasına etki edeceğinin akılda tutulması gerekir. Metnin hiyerarşisi ve hiyerarşinin çizimlerle nasıl ilişkilendirildiği üzerine düşünmek lazımdır” (Farrelly, 2012, s. 158).

Grafik sunumlarda tipografide boyut ve yazı tipi kullanımının yanında renk unsuru da görsel etkiye oldukça katkı sağlamaktadır. Göz temel olarak renk değişimden ziyade kontrast yani zıt renklere daha hassastır. Beyaz yüzeyde büyük koyu alanları daha çabuk algılar veya tam tersi koyu zemin üzerinde büyük açık alanları daha çabuk algılar. Örneğin, beyaz bir zeminde sarı renkte bir yazının, siyah bir zemindekine göre kontrast farkının az olmasından dolayı okunması daha zor olacaktır. Tam tersi düşünüldüğünde, siyah zemin ile diğer renklerin kontrast farkı çok olacağından sarı ya da beyaz yazının okunması daha kolay, fakat koyu mavi bir yazının okunması oldukça zor olacaktır. Bu nedenle beyaz zeminli paftalarda, özellikle destekleyici metinlerde, küçük bir punto değeri ve light ya da regular bir versiyon kullanıldığında mümkün olduğunca koyu bir renk tercihi yapılmalıdır. Beyaz ya da krem renginin kullanım tercihinin fazla olması gerekliliği ile burada da karşılaşılmaktadır. Bazı durumlarda mimari projenin görselinin üzerinde de metin kullanılmaktadır. Bu gibi durumlarda metin, bir kutu içerisinde uygulanmalı ya da görselin fazla yoğun olmadığı alanlarda kullanılmalıdır.

Tüm bunların yanında tipografinin biçimsel sunumu kadar içeriksel sunumu da önem taşımaktadır.

Grafiksel bir mesajın okunabilirliği içerik ve sunumuyla belirlenir. Bir mesajın okunabilirliği, okuyucunun yazı stilini ve resimlerini anlama yeteneğini içerir. Okuyucunun dikkatinin dağılmaması için dil tarzı ve üslup kullanımı doğru olmalıdır. Stil, kelimelerin seçimine, tutarlılığına, ifadelerine, resim öğelerine, sembollere ve grafik tasarımına bağlıdır. Soyut sözler, jargon, uzun ve karmaşık cümleler, pasif yapılar ve stilize dil okumayı engelleyebilir (Pettersson, 2010, s. 173).

\subsection{Beyaz Alanlar}

2 Boyutlu bir tasarım yüzeyinde yer alan grafik ve metin gibi unsurları çevreleyen boş bırakılmış alan beyaz alan olarak nitelendirilir. İsviçreli tasarımcı Jan Tschichold (1902-1974) modernist bir tasarım değeri olarak beyaz alan kullanımını savunmuştur ve beyaz alanları, diğer tasarım unsurlarının nefes almasına izin verdikleri için "tasarımın akciğerleri” olarak adlandırmıştır (Ambrose ve Harris, 2011a, s. 42). Beyaz alanlar ayrıca tasarıma seçkinlik duygusu da katmaktadır. Görsel hiyerarşiyi sağlayan kavramlar boşluk, renk, boyut ve yerleşim olarak nitelendirildiğinde beyaz alanlar, görsel ve tipografik elemanların kendi aralarındaki ilişkiye dikkat çeker. Bununla birlikte beyaz alan kullanımı tasarım içerisinde hiyerarşi yaratmak üzere kullanılabilecek sakin boşluklar yaratır (Ambrose ve Harris, 2011a, s. 42).

\subsection{Vurgu}

Tasarımda dikkat çekmek istenen bölümü niteler. Renk, form gibi yöntemlerle sağlanabilir. Vurgu, aynı zamanda dikkati yönlendirmek ve dikkatini tutmak veya bilgi materyallerinde belirli noktaları dramatize etmek için de kullanılabilir (Pettersson, 2010, s. 174). Bilginin sunumunu bir hikâyenin tipografik ve grafik ifadesi olarak değerlendirildiğinde bu sunumda bir anafikirde olacaktır ve literatürde vurgu ya da vurucu odak şeklinde ifade edilen kavramların, ana fikir kavramına karşılık geldiği söylenebilir. The City University of New York'un Mimari Teknoloji Bölümü tarafından Slide Share sitesinde yayınlanan Mimari Sunumlar ile ilgili bir sunuma göre de ana fikri ilk bakışta dikkati çekecek şekilde yerleştirmek gerekmektedir.

\subsection{Bütünlük}

Bir tasarım yüzeyinde var olan bütünsel uyumdur. Her tasarım yüzeyinde yer alan görsel ve tipografik bileşenlerin arasındaki uyumda kendine has bir tarz yatmaktadır. Bu durum görsel dile karşılık gelmektedir. Tasarım elemanlarının yüzeydeki dengeli ve uyumlu dağılımı bütünlüğ̈ meydana getirir. Böylece göz bu elemanlar arasında rahatça gezinebilir. "Bilgi kümeleri birliğe ve "genel bir beraberliğge" sahip olmalıdır. Bir materyaldeki her türlü tutarsızlık alıcıları şaşırtabilir. Mesajın amaçlanan içeriğini yorumlamaları ve anlamaları, gereksiz yere karmaşık bir hale gelebilir" (Pettersson, 2010, s. 174).

\subsection{Denge}

Her görsel elemanın, tasarım yüzeyinde bir ağırlığı bulunmaktadır. Bu elemanların birbiri ile olan doğru ilişkileri neticesinde ise denge unsurundan söz edilebilir. Paftalarda da, piktogram, sunuş çizimi ya da metin gibi elemanların birbirleri olan ilişkilerle belirlenir. Denge, yalnızca simetrinin kurulması ile sağlanabilecek bir durum değildir, büyük küçük ilişkisi ya da renk vasıtasıyla tasarımda denge sağlanabilir.

\subsection{Yakınlık}

Birbiri ile ilişkilendirilecek elemanların arasında oluşturulacak olan mesafeler, yakınlık ifadesine karşılık gelmektedir. Tasarım yüzeylerinde, birbirine yakın olan elemanları birbiri ile ilişki, uzak olanlar ise birbiri ile ilişkisiz olarak değerlendirilir. Örneğin, bir görseli anlatan metin mümkün olduğunda bu görsele yakın bir biçimde konumlandırılmalıdır. Yakınlık, bir algılama ilkesi olarak da değerlendirilebilir. 


\section{Sonuç}

Bir mimarlık öğrencisi ya da sektörde çalışan bir mimar için paftalar, projelerini sunmak için bir araç, aynı zamanda onların bir bakıma imzası niteliğindedir. Projelerin başarısı sunum yoluyla ifade edilirken, paftaların görsel sunumu önemi de değer kazanmaktadır. Bu doğrultuda, paftaların içerdiği görsel ve tipografik bileşenlerin misyonu ve bunların belirli bir akış içerisinde sunulma durumu, çoğu zaman izleyiciyi ikna etme gerekliliği ya da yalnızca bilgiyi karşı tarafa etkili bir şekilde aktarabilme kaygısı, mimari paftaların grafik tasarımın, hatta bu disiplinin bir alt alanı olan bilgilendirme tasarımı kapsamında değerlendirilmesi gerekliliğini ortaya koymaktadır. İsveç Mälardalen Üniversitesi Bilgilendirme Tasarımı Bölümü’nde Bölüm Başkanı olarak görev yapmış olan Prof. Rune Pettersson'a göre (Pettersson, 2012); "Bilgilendirme tasarımı, alıcıların bilgi ihtiyacını karşılamak amacıyla bir mesajın analizi, planlanması, sunumu ve onun içeriği, dili ve formunun anlaşılmasını kapsar”. Kimi zaman bir gazetede, kimi zaman 2 boyutlu bir eğitim materyalinde karşılaşabileceğimiz infografikler, nicel bilgilerin diyagramlarla, nitel bilgilerin ise illüstrasyon ya da piktogram gibi sembollerle bir bakıma özetleyerek, bilginin en ekonomik biçimde karşı tarafa etkili bir şekilde aktarılmasını, bunu yaparken de çalışmanın işlevi ya da hedef kitleye göre izleyiciyi ikna etmeyi fakat en önemlisi en yalın ifade biçim ve yöntemleriyle karmaşık bilgi kümesini akılda kalıcı bir şekilde sunmayı amaçlar. Bilgilendirme tasarımlarında olduğu gibi mimari paftalarda da görsel tasarım ilkelerinden yararlanmanın dikkat çekmeye, okunurluğa ve akılda kalıcılığa etkisi oldukça büyük olacaktır.

Son yıllarda mimarların projelerini uygulama ve sunma yöntemleri de grafik tasarımcılarla ister istemez benzerlik göstermekte, mimarlar da bilgisayar destekli programlar yararlanmakta, Adobe Illustrator, Adobe Indesign ve Adobe Photoshop gibi vektör ve piksel tabanlı programları öğrenme yoluna gitmektedir. Öyle ki konu ile ilgili internet üzerinden satın alınarak izlenebilecek bazı online eğitimler bulunmaktadır. Online 3D Eğitim mottosuyla yola çıkan truvadesign.tv'de "Mimari Projeler için Pafta Oluşturma" başlıklı bir eğitimi bulunmaktadır. Eğitim kapsamında mimarlar için fotoğrafların PS (Adobe Photoshop) ile geliştirilmesi, mimari görselleştirme teknikleri, pafta layoutu oluşturma, pafta bileşenlerinin yerleştirilmesi ile ilgili dersler yer almaktadır. Bunun yanında etkili mimari posterler hazırlamak için www.showitbetter.co gibi eğitici web sitelerinin var olması ya da Pinterest gibi platformlarda yüzlerce sunum posterlerinin paylaşılması, neredeyse mimarlar arasında projelerinin başarısı dışında poster tasarımlarının başarısı doğrultusunda da bir rekabet ortamına zemin oluşturur gibidir.

Görüntüleme tekniklerinin değişim göstermesiyle birlikte sunum teknolojileri de günden güne gelişmektedir. Geleneksel mimari görselleştirme tekniklerinin yerini 3D yazıcılarla hazırlanan teknolojik sunum yöntemleri almaya başlasa da diğer bileşenlerle sunumu, VR ve hologram gibi teknolojilerin günümüzde kullanımının yaygınlaşmasına kadar geçecek süre içerisinde kullanımı devam edecektir.

\section{Kaynakça}

Ambrose, G., \& Harris, P. (2011a). Görsel grafik tasarım sözlüğ̈̈̈. İstanbul: Literatür Yayıncılık.

Ambrose, G., \& Harris, P. (2011b). Tipografinin temelleri, Akademik Temeller Dizisi: 08. İstanbul: Literatür Yayıncilik.

Ambrose, G., \& Harris, P. (2013). Grafik tasarımda sayfa düzeni, Grafik Tasarım Temelleri 04. İstanbul: Literatür Yayıncılik

Burotime. (2019). Mimari Proje Sunum Paftası Nasıl Hazırlanır?, Erişim adresi: https://blog.burotime.com/ mimari-proje-sunum-paftasi-nasil-hazirlanir/

Demiralp, N. (2009). Haritalarla öğrenme. Türk Ĕ̆itim Bilimleri Dergisi, 7(4), 955-973.

Dulic, O., \& Aladzic, V. (2016, Nisan). A Note On Graphical Representations In Architecture-Diagrams Over Sketches. 4. Uluslararası İnşaat Mühendisliğinde Çağdaş Başarılar Konferasında sunulan bildiri, Novi Sad Üniversitesi, Sırbistan. Erişim adresi: http://www.gf.uns.ac.rs/ zbornik/doc/NS2016.084.pdf

Farrelly, L. (2012). Mimarlıkta sunum teknikleri. İstanbul: Literatür Yayınc1lık.

Güler, T. (2016). Yazılı Tarihin Başlangıcından Günümüz Dünyasına Piktogramların İşlevi Üzerine Bir Değerlendirme, Idil Dergisi, 5(25). doi: https://doi.org/10.7816/idil-05-25-10

İnan, N., \& Yıldırım, T. (2009). Mimari tasarım sürecinde disiplinlerarasi ilişkiler ve eşzamanlı - dijital ortam tasarım olanakları. Gazi Üniversitesi Mühendislik Mimarlık Fakültesi Dergisi, 24(4), 583-595. Erişim adresi: http://www.mmfdergi.gazi.edu.tr/article/view/1061000199/1061000170

Köksal, A. (2009). Anlamın sırları. İstanbul: Arkeoloji ve Sanat Yayınları.

Martin, H. (2018). “Hibrid Tasarımcılar Aranıyor”, Yazılar, Sayı: 186

Melikoğlu Eke, A. (2019). Düşünmenin ve Tasarlamanın Yaratıcı Araçları. The Turkish Online Journal of Design, Art and Communication, 9(3), 358-366. Erişim adresi: https://dergipark.org.tr/en/download/article-file/743391 
Mewburn, C. (2015, 23 Ekim). Layout Presentation. Erişim adresi: https://www.youtube.com/watch?v=jsh82 rjLjw

Öztuna, Y. (2007). Görsel iletişimde temel tasarım. İzmir: Tibyan Yayıncılık.

Pektaş, Ş. T. (2009). Mimarlıkta yapı bilgi modellemesi uygulamaları. Mimarlık, Mimarlar Odası, Sayı: 346

Pettersson, R. (2010). Information design-principles and guidelines, Journal of Visual Literacy, 29(2), 167-182.

Pettersson, R. (2012). It depends-principles and guidelines. Erişim adresi: http://www.iiid.net/PublicLibrary/ Pettersson-Rune-ID-It-Depends.pdf

Xulong. (2017). Architecture presentation board layout techniques in photoshop. Erişim adresi: https://medium. com/dpro/architecture-presentation-board-layout-techniques-in-photoshop-df500bf2ce01

\section{Görsel Kaynakçası}

Görsel 1. Mimarlar için online bir kursun tanıtım görseli. (2019), [Görsel]. Erişim adresi: https://coursesfirstinarchitecture.co.uk/p/photoshop-for-architects-basics-course

Görsel 2. Udemy'de mimarlara yönelik bir online kursun tanıtım videosu. (2019), [Video]. Erişim adresi: https://www.udemy.com/course/photoshop-visualisation-for-architects/

Görsel 3. Hipergerçekçi bir render örneği. (2019), [Render]. Erişim adresi: https://www.archdaily.co/co/ 797971/los-15-mejores-proyectos-de-fin-de-carrera-en-mexico

Görsel 4. Mimari Piktogramlar. (2019), [Sunum]. Erişim adresi: https://www.slideshare.net/gopaltry/plan-symbols

Görsel 5. Bir diyagram örneği. (2019), [Diyagram]. Erişim adresi: https://www.arch2o.com/tips-architectureproject-presentation/

Görsel 6. Farklı Layout düzenleri. (2019), [Video]. Erişim adresi: https://www.youtube.com/watch?v= dqC5RBYW1HE

Görsel 7. Grid Pafta Örneği. (2019), [Video]. Erişim adresi: https://www.youtube.com/watch?v=dqC5RBYW1HE

Görsel 8. Beyaz alan kullanımına örnek. (2019), [Tasarım]. Erişim adresi: https://archinect.com/news/gallery/ 74318284/7/winners-of-australia-s-the-lodge-on-the-lake-competition

Görsel 9. Koyu zeminde bileşenlerin ideal sunumuna örnek. (2019), [Tasarım]. Erişim adresi: https://www.archdaily.com/593683/malaysia-airlines-flight-17-victims-honored-with-memorial-in-the-sky/

Görsel 10. F Pattern. (2013), [Görsel]. Ambrose, G., \& Harris, P. (2013). Grafik tasarımda sayfa düzeni, Grafik Tasarım Temelleri 04. İstanbul: Literatür Yayıncılık

Görsel 11. Tipografinin zeminle kontrast ilişkisine örnek. (2019), [Tasarım]. Erişim adresi: https://www.arch2o.com/tips-architecture-project-presentation/ 